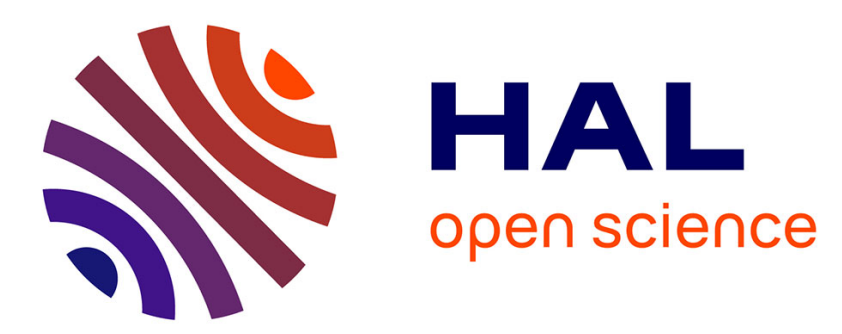

\title{
Population structure and genetic diversity of the orchid bee Eufriesea violacea (Hymenoptera, Apidae, Euglossini) from Atlantic Forest remnants in southern and southeastern Brazil
}

Gabriele Freiria, Juliana Ruim, Rogério Souza, Silvia Sofia

\section{To cite this version:}

Gabriele Freiria, Juliana Ruim, Rogério Souza, Silvia Sofia. Population structure and genetic diversity of the orchid bee Eufriesea violacea (Hymenoptera, Apidae, Euglossini) from Atlantic Forest remnants in southern and southeastern Brazil. Apidologie, 2012, 43 (4), pp.392-402. 10.1007/s13592-011-0104y . hal-01003527

\section{HAL Id: hal-01003527 \\ https://hal.science/hal-01003527}

Submitted on 1 Jan 2012

HAL is a multi-disciplinary open access archive for the deposit and dissemination of scientific research documents, whether they are published or not. The documents may come from teaching and research institutions in France or abroad, or from public or private research centers.
L'archive ouverte pluridisciplinaire HAL, est destinée au dépôt et à la diffusion de documents scientifiques de niveau recherche, publiés ou non, émanant des établissements d'enseignement et de recherche français ou étrangers, des laboratoires publics ou privés. 


\title{
Population structure and genetic diversity of the orchid bee Eufriesea violacea (Hymenoptera, Apidae, Euglossini) from Atlantic Forest remnants in southern and southeastern Brazil
}

\author{
Gabriele Antico Freiria ${ }^{1}$, Juliana Bombarda Ruim ${ }^{1}$, Rogério Fernandes de SouzA ${ }^{2}$, \\ Silvia Helena SofiA ${ }^{1}$ \\ ${ }^{1}$ Laboratório de Genética e Ecologia Animal, Departamento de Biologia Geral, Universidade Estadual de Londrina, \\ Rodovia Celso Garcia Cid km 380, 86051-980 Londrina, Paraná, Brazil \\ ${ }^{2}$ Laboratório de Bioinformática, Departamento de Biologia Geral, Universidade Estadual de Londrina, Rodovia \\ Celso Garcia Cid km 380, 86051-980 Londrina, Paraná, Brazil
}

Received 13 July 2011 - Revised 5 September 2011 - Accepted 2 October 2011

\begin{abstract}
In this study, both the genetic diversity and population genetic structure of Eufriesea violacea from six Atlantic Forest fragments, located in four Brazilian states, were assessed using microsatellite markers. The results showed that genetic diversity was high in all populations and the genetic differentiation $\left(\Phi_{\mathrm{ST}}\right)$, based on allelic frequency differences, for all population pairwise comparisons was found to be significantly different from zero, indicating from low to moderate genetic differentiation among populations. Considerably higher genetic differentiation values were revealed by the $D_{\text {est }}$ estimator, indicating very high levels of differentiation for some pairs of populations. The present results on the population structure of $E$. violacea suggest a restriction in gene flow among populations from different Atlantic Forest remnants. Thus, considering the intense threats over the current Atlantic Forest remnants, more attention should be paid to populations of this euglossine species.
\end{abstract}

genetic variation / euglossine bees / forest fragments / microsatellites

\section{INTRODUCTION}

In the last decade, strong evidence for a decline in bee populations worldwide has generated several ecological and economical concerns (Biesmeijer et al. 2006; Gallai et al. 2009; Grixti et al. 2009), since bees are considered the main pollinator group in both agricultural and natural ecosystems (Neff and Simpson 1993; Kevan and

Corresponding author: S. H. Sofia shsofia@uel.br

Manuscript editor: Klaus Hartfelder
Phillips 2001). Different factors have contributed to this decline, including habitat destruction and fragmentation, modern agricultural practices and the use of pesticides and climate change (Cane 2001; Freitas et al. 2009; Murray et al. 2009; Zayed 2009; Martins and Melo 2010).

Considered one of the hotspots of biodiversity on the planet (Myers et al. 2000) and representing in the past one of the largest rainforests of the Americas, the Brazilian Atlantic Forest is currently totally fragmented, due to intense process of the deforestation and anthropogenic occupation which began about 500 years ago and extends to the present days (Morellato and Haddad 2000; 
Ribeiro et al. 2009; Fundação SOS Mata Atlântica and INPE 2010). The majority of the remaining Atlantic Forest exists in small fragments, in different stages of vegetation succession, which are isolated from each other (Ribeiro et al. 2009). It is within this fragmented landscape that native bees and other groups of animals still found daily resources necessary for their survival. Despite habitat fragmentation, considered to be one of the main causes of pollinator decline (Kremen et al. 2002, 2007; Klein et al. 2007; Brosi et al. 2008), very few empirical studies have addressed the effects of forest fragmentation on bees (Brosi et al. 2008).

Among bees, euglossines (Apidae: Euglossini) comprise a group of approximately 200 species found exclusively in the tropical Americas (Cameron 2004; Roubik and Hanson 2004), from which about 50 species are known to be endemic to the Atlantic Forest (Peruquetti et al. 1999; Nemésio 2009). Widely recognised as important pollinators in Neotropics, euglossine bees are important pollinating agents of different species belonging to over 30 tropical plant families, while about 700 orchid species are pollinated exclusively by euglossine males (Dressler 1982; Ackerman 1983; Roubik and Hanson 2004). Despite their importance in the maintenance of gene flow across Neotropical forests, a number of studies have suggested that euglossine bees are sensitive to forest fragmentation and a reduction in the size of forest fragments (Powell and Powell 1987; Sofia and Suzuki 2004; Brosi et al. 2008; Brosi 2009). On the other hand, genetic studies involving different orchid bee species have shown that even in fragmented landscape scenarios, some species have maintained high levels of population genetic diversity (Sofia et al. 2005; Suzuki et al. 2010; Cerântola et al. 2011; Zimmermann et al. 2011).

Among the Euglossini, Euglossa chalybeata Friese, Euglossa analis Westwood, Eufriesea violacea (Blanchard) and other species have been identified as sensitive to forest fragmentation (Powell and Powell 1987; Tonhasca et. al. 2002; Giangarelli et al. 2009). E. violacea is a seasonal species, exhibiting a univoltine annual life cycle (Peruquetti and Campos 1997), distributed across
Brazilian, Paraguayan and Argentinean territories (Kimsey 1982). In Brazil, this species is found almost exclusively in the Atlantic Forest (Nemésio and Silveira 2007), occurring in seven states throughout southern and southeastern regions (Nemésio 2009).

A study on the genetic diversity and population structure of $E$. violacea from three forest fragments distributed in a restricted and regional scale, based on random amplified polymorphic DNA (RAPD) markers, revealed the occurrence of high levels of genetic variation and a single panmitic population in the studied region (Sofia et al. 2005). These authors attributed their results to possible gene flow between bees from the three fragments or to the recent history of forest fragmentation in the region. However, considering that genetic studies provide insights into population structure and genetic variation that are crucial for conservation management (Davis et al. 2010), and since populations of E. violacea populations could be suffering declines in their populations (Giangarelli et al. 2009), more studies concerning the genetic populations of this species are still necessary. Moreover, many characteristics of these bees, including their characteristic endemism and distribution intimately associated with the Atlantic Forest (Nemésio and Silveira 2007) and recent origin (Ramírez et al. 2010), among others, make them objects of particular interest for conservation approaches.

Thus, in the current study, we assessed the genetic diversity and population genetic structure of $E$. violacea surveyed across a large range of the distribution of this species in Atlantic Forest remnants in southern and southeastern Brazil.

\section{MATERIAL AND METHODS}

\subsection{Study sites}

This study was conducted in six remnants of the Atlantic Forest. Three are located in the state of Paraná: (1) "Fazenda Santa Maria" (PR1), (2) "Parque Estadual Mata dos Godoy" (PR2) and (3) "Fazenda Monte Alegre" (PR3). In three other states, only one location was sampled: (4) "Nazaré Paulista" (SP1), a fragment 
present in the state of São Paulo, (5) "Centro de Pesquisas e Conservação da Natureza Pro-Mata (CPCN-Pró Mata)" (RS1), in the state of Rio Grande do Sul and (6) "Estação Experimental da Empresa de Pesquisa Agropecuária e Extensão Rural de Santa Catarina S/A (EPAGRI)", in the state of Santa Catarina (SC1) (Figure 1; Table I). The distance between these fragments ranges from 130 to $850 \mathrm{~km}$.

\subsection{Bee sampling}

The sampling method was based on the methods of Sofia and Suzuki (2004). Bees were sampled simultaneous by two collectors positioned at two different sites in each forest fragment. Males of E. violacea were collected with an insect net when they were attracted to scent baits of eugenol, eucalyptol and vanillin, from 10:00 am to 1:00 pm, during November and December of 2008 and 2009. Samplings were carried out preferentially in sunny days. The captured bees were placed in plastic tubes, transported alive to the laboratory and stored at $-20^{\circ} \mathrm{C}$ until DNA analysis. Except for the fragment PR1, where only 53 males were surveyed, 60 males were captured and analysed per fragment (PR2, PR3, SP1, RS1 and SC1). In these five forest fragments, a similar effort of sampling was employed, which ranged in number from one (SP1, RS1 and SC1) to two (PR2 and PR3) per fragment studied. Only fragment PR1 demanded a higher effort of sampling (five surveys).

\subsection{DNA extraction and microsatellite amplification and analysis}

Prior to DNA isolation, the bees were rinsed individually with $70 \%$ alcohol on a sterile plate to remove exogenous material. Next, DNA was extracted from the insect thorax. Samples were then incubated with proteinase $\mathrm{K}(100 \mu \mathrm{g} / \mu \mathrm{L})$ and extraction buffer (1\% SDS, $200 \mathrm{mM}$ Tris-HCl, $250 \mathrm{mM} \mathrm{NaCl}, 25 \mathrm{mM}$ EDTA, $\mathrm{pH} 8.0$ ) for $2 \mathrm{~h}$ at $64^{\circ} \mathrm{C}$. The DNA concentration was determined using a DyNA Quant 200 fluorometer (Hoefer) using Hoechst 33258 dye and was diluted so that all DNA samples were at a standard concentration $(0.5 \mathrm{ng} / \mu \mathrm{L})$. Isolates were then used immediately or stored at $-20^{\circ} \mathrm{C}$.

Six microsatellite loci (Eln 12b, Eln 7J, Eln 12J, Eln 2J, Egc 17 and Egc 18) were amplified according to the protocol of Souza et al. (2007), with some modifications. Each PCR reaction was carried out in a $15-\mu \mathrm{L}$ solution containing $2 \mu \mathrm{L}$ of DNA template, $0.25 \mathrm{mM}$ of each dNTP (GE Healthcare), $1 \mathrm{mM}$ of each primer, $2.0 \mathrm{mM}$ of $\mathrm{MgCl}_{2}$ (BioTools), $1 \times$ buffer (BioTools), $1 \mathrm{U}$ Taq polymerase (BioTools) and sterile water. The PCR products were amplified in a thermocycler (MJ Research PTC 100), and the amplification protocol consisted of $4 \mathrm{~min}$ at $94^{\circ} \mathrm{C}$, followed by 29 cycles of $30 \mathrm{~s}$ at $94^{\circ} \mathrm{C}, 30 \mathrm{~s}$ at $51^{\circ} \mathrm{C}$ (Eln $12 \mathrm{~J}), 54^{\circ} \mathrm{C}(\mathrm{E} \ln 2 \mathrm{~J} ; \mathrm{E} \ln 12 \mathrm{~b} ; \mathrm{Eln} 7 \mathrm{~J}), 56^{\circ} \mathrm{C}(\mathrm{Egc}$ 17) or $57^{\circ} \mathrm{C}(\mathrm{Egc} 18)$, and $1 \mathrm{~min}$ at $72^{\circ} \mathrm{C}$. An aliquot $(10 \mu \mathrm{L})$ of the PCR product was electrophoresed in

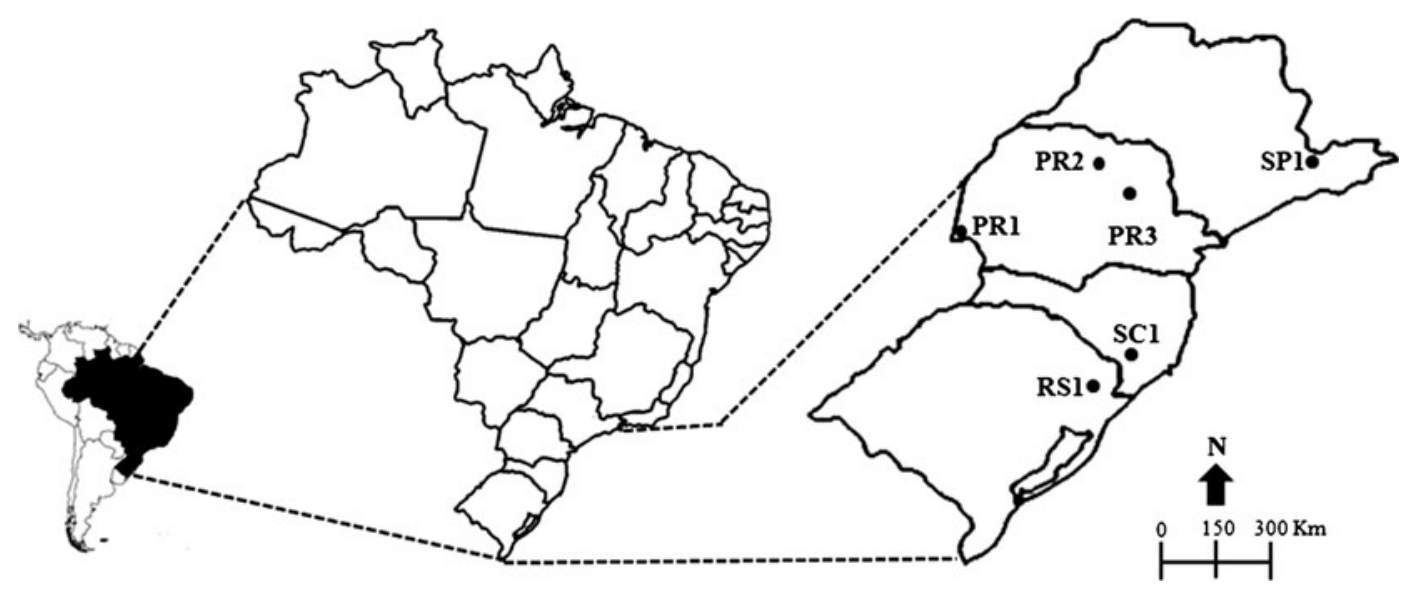

Figure 1. Map of Brazil showing the six localities in four states where males of $E$. violacea were surveyed. The sampling sites codes (SP1, PR1, PR2, PR3, SC1 and RS1) were described in Table I. 
Table I. Site code, location (including, respectively, the municipality, geographic position in the Brazilian state, and Brazilian region, this last indicated in parenthesis), geographic coordinates, fragment size and type of vegetation of the six localities where males of E. violacea were surveyed.

\begin{tabular}{lllll}
\hline $\begin{array}{l}\text { Site } \\
\text { code }\end{array}$ & Location & Coordinates & Size (ha) & Vegetation type \\
\hline PR1 & $\begin{array}{c}\text { Santa Terezinha de Itaipu, western Paraná } \\
\text { state (Southern) }\end{array}$ & $25^{\circ} 25^{\prime} \mathrm{S} ; 54^{\circ} 25^{\prime} \mathrm{W}$ & 280 & Semidecidual forest \\
PR2 & $\begin{array}{c}\text { Londrina, northern Paraná state (Southern) } \\
\text { Pelêmaco Borba, center-eastern Paraná state } \\
\text { PR3 }\end{array}$ & $\begin{array}{c}23^{\circ} 27^{\prime} \mathrm{S} ; 51^{\circ} 14^{\prime} \mathrm{W} \\
24^{\circ} 05^{\prime} \mathrm{S} ; 50^{\circ} 42^{\prime} \mathrm{W}\end{array}$ & 217 & $\begin{array}{c}\text { Semidecidual forest } \\
\text { Semidecidual forest }\end{array}$ \\
SP1 & $\begin{array}{c}\text { Nazaré Paulista, southeastern São Paulo state } \\
\text { (Southern) }\end{array}$ & $23^{\circ} 14^{\prime} \mathrm{S} ; 46^{\circ} 20^{\prime} \mathrm{W}$ & 2,809 & Tropical rain forest \\
RS1 & $\begin{array}{c}\text { São Francisco de Paula, southeastern Rio Grande } \\
\text { do Sul state (Southern) }\end{array}$ & $29^{\circ} 28^{\prime} \mathrm{S} ; 50^{\circ} 9^{\prime} \mathrm{W}$ & 1,778 & Araucaria forest \\
SC1 & Urussanga, Santa Catarina state (Southern) & $28^{\circ} 32^{\prime} \mathrm{S} ; 49^{\circ} 18^{\prime} \mathrm{W}$ & 630 & Tropical rain forest \\
\hline
\end{tabular}

nondenaturing $8 \%$ polyacrylamide gels in $1.0 \times \mathrm{TBE}$ buffer, stained with silver nitrate, photographed and analysed. Allele lengths were estimated by comparison with 10 bp DNA ladder, using Fragment Length Calculator software (Ray 2000).

\subsection{Data Analyses}

To test for linkage disequilibrium among pairs of loci, GENEPOP web 3.4 (Raymond and Rousset 1995; Rousset 2008) was employed, using 10,000 permutations to assess significance; sequentially, $p$ values were adjusted by the Bonferroni correction (Rice 1989).

Assuming Hardy-Weinberg equilibrium, unbiased expected heterozygosity $\left(H_{\mathrm{e}}\right)$ in each population and for all populations (total expected heterozygosity, $H_{\mathrm{e}-\mathrm{T}}$ ) were estimated using TFPGA software (Miller 1997). Both estimates were also analysed by FSTAT software (Goudet 1995) using diploidised male microsatellite data. In addition, FSTAT was used to calculate allelic richness $(A \mathrm{r})$. One locus was considered polymorphic when the frequency of the most common allele was smaller than 95\% (Cerântola et al. 2011).

To evaluate the apportioning of genetic variation within and among sampling localities, an analysis of molecular variance (AMOVA) was performed using the software Arlequin version 3.5 (Excoffier and Lischer 2010). Variance components were tested statistically by nonparametric permutation procedures, using 1,000 permutations, and were considered significant at $p$ values $<0.05$.
In view of the concern over the efficiency of $F_{\mathrm{ST}}$ and its relatives ( $G_{\mathrm{ST}}, \Phi_{\mathrm{ST}}$ and others) to detect levels of genetic differentiation between subpopulations at highly polymorphic loci (Hedrick 2005; Jost 2008), including microsatellite loci, genetic differentiation was also calculated by the $D_{\text {est }}$ estimator (Jost 2008) using the SPADE software (Chao and Shen 2003). $D_{\text {est }}$ is a measure based on the proportion of alleles that are unique to a subpopulation, and it is independent of the average within-subpopulation heterozygosity (Jost 2008).

All analyses were carried out excluding diploid males when these were detected among males surveyed at different sampling sites, since the majority software used in the analyses do not allow data sets including a combination of haploid and diploid genotypes. Thus, since our data set includes only haploid individuals (males), and as a consequence, it is not possible here to assess the HardyWeinberg equilibrium condition for the populations surveyed, it was assumed that all populations were under Hardy-Weinberg equilibrium with equal allele frequencies between the sexes (Lopez-Uribe et al. 2007).

To test for isolation by distance (IBD), pairwise estimates of genetic distances $\left(\Phi_{\mathrm{ST}} /\left(1-\Phi_{\mathrm{ST}}\right)\right.$, analogous to $F_{\mathrm{ST}} /\left(1-F_{\mathrm{ST}}\right)$; Rousset 1997) were regressed on geographical distances (kilometres) between different sites, using a Mantel test, performed by TFPGA software (Miller 1997). In addition, pairwise values of $D_{\text {est }} /\left(1-D_{\text {est }}\right)$ were similarly plotted against 
geographical distances aiming to verify possible correlations between both measures.

Kruskal-Wallis test was employed to test differences among mean expected intraloci heterozygosity from each population. All statistical tests were performed using a significance level of $5 \%$.

\section{RESULTS}

\subsection{Genetic diversity}

In total, 353 males of E. violacea from six populations were genotyped at six microsatellite loci and all these loci were polymorphic in the six populations surveyed. Of these 353 males, eight were found to be diploid for different microsatellite loci (data not shown) and were not included in the analysis.

The analyses showed that all pairs of microsatellite loci were in linkage equilibrium $(P>0.05)$, after adjusting to the nominal $5 \%$ level with the Bonferroni correction for four pairs. The number of alleles per locus ranged from 3 (locus Eln 2J) to 11 (locus Egc 18), averaging 7.6 alleles found per locus. We found no tendency for any locality to be generally more or less diverse than another. The average number of alleles per population varied from 6 (PR1 e PR2) to 6.8 (RS1), revealing a low range of variation among populations. Considering the mean expected heterozygosity $\left(H_{\mathrm{e}}\right)$, this measure of genetic diversity ranged from 0.70 (population PR2) to 0.77 (RS1), not differing substantially among populations (Table II); the mean global expected heterozygosity $\left(H_{\mathrm{e}-\mathrm{T}}\right)$ was found to be 0.74 . The locus Eln 2J was the least variable, showing measures of $H_{\mathrm{e}}$ ranging from 0.53 to 0.63 , while the locus Egc 18 was the most variable $\left(H_{\mathrm{e}-\mathrm{T}}=0.84\right)$, exhibiting a low variation of $H_{\mathrm{e}}$ among populations (ranging from 0.82 to 0.86 ). Mean expected intraloci heterozygosity did not differ significantly among populations. Allelic richness $\left(A_{\mathrm{r}}\right)$ ranged between 3.00 and 10.27.

\subsection{Genetic structure}

In total, only two private alleles were detected, one each in the following populations: PR2 (locus Eln 12b), and PR3 (Egc 18). Also, some alleles were surveyed in two or three populations, such as allele 8 (locus Egc 17) found only in populations RS1 and SC1 (Figure 2).

The AMOVA, employed to assess the partition of genetic variation, indicated that $95.61 \%$ of the total variation was contained within populations (sum of squares $(\mathrm{SS})=747.2, d f=347$, variance component $=0.099$ ), while $4.39 \%$ represents the differences among populations (samples) $(\mathrm{SS}=$ $39.85, d f=5$, variance component $=2.15$ ) , however, global $\Phi_{\mathrm{ST}}(0.0439)$ was found to be significantly different from zero $(P<0.01)$.

Table II. The global expected heterozygosity $\left(H_{\mathrm{e}-\mathrm{T}}\right)$ and standard deviation $( \pm \mathrm{SD})$, intra-locus expected heterozygosity and mean expected heterozygosity $\left(H_{\mathrm{e}}\right)$ and associated standard deviation $( \pm \mathrm{SD})$ in populations of $E$. violacea from six Brazilian localities (SP1, PR1, PR2, PR3, RS1 and SC1).

\begin{tabular}{|c|c|c|c|c|c|c|c|c|}
\hline \multirow[t]{2}{*}{ Locus } & \multicolumn{6}{|c|}{ Populations } & \multirow[t]{2}{*}{$H_{\mathrm{e}-\mathrm{T}}$} & \multirow[t]{2}{*}{$\pm \mathrm{SD}$} \\
\hline & PR1 & PR2 & PR3 & SP1 & RS1 & $\mathrm{SC} 1$ & & \\
\hline$E \ln 2 \mathrm{~J}$ & 0.59 & 0.53 & 0.62 & 0.63 & 0.60 & 0.54 & 0.59 & 0.04 \\
\hline$E \ln 7 \mathrm{~J}$ & 0.78 & 0.80 & 0.81 & 0.82 & 0.79 & 0.83 & 0.80 & 0.02 \\
\hline Eln $12 b$ & 0.67 & 0.58 & 0.57 & 0.53 & 0.70 & 0.70 & 0.63 & 0.07 \\
\hline Eln 12J & 0.81 & 0.78 & 0.84 & 0.80 & 0.81 & 0.83 & 0.81 & 0.02 \\
\hline Egc 17 & 0.75 & 0.69 & 0.66 & 0.70 & 0.84 & 0.82 & 0.74 & 0.07 \\
\hline Egc 18 & 0.82 & 0.84 & 0.86 & 0.83 & 0.85 & 0.85 & 0.84 & 0.01 \\
\hline$H_{\mathrm{e}}$ & 0.74 & 0.70 & 0.73 & 0.72 & 0.77 & 0.76 & 0.74 & 0.02 \\
\hline$\pm \mathrm{SD}$ & 0.08 & 0.11 & 0.11 & 0.11 & 0.09 & 0.11 & 0.10 & - \\
\hline
\end{tabular}


A)

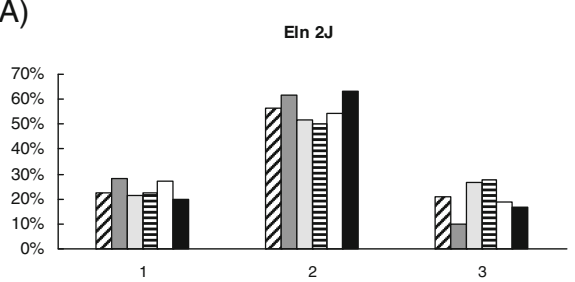

B)

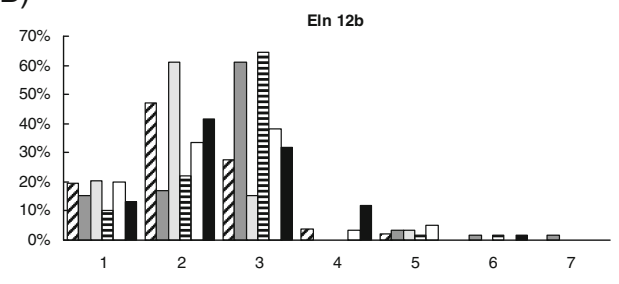

C)

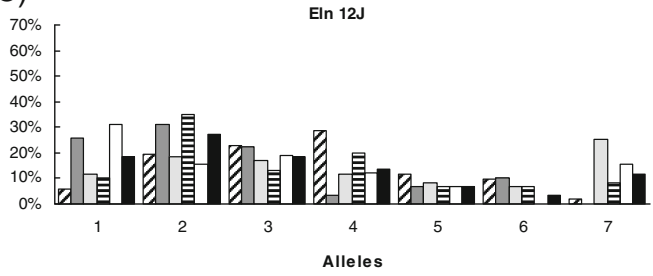

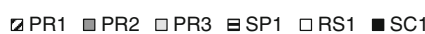

D)

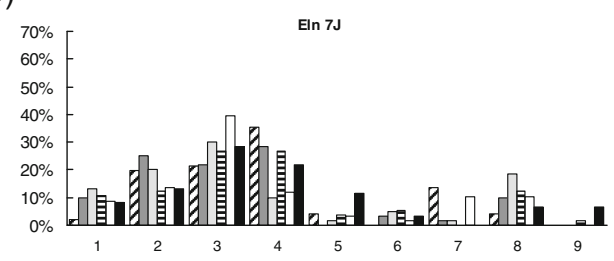

E)

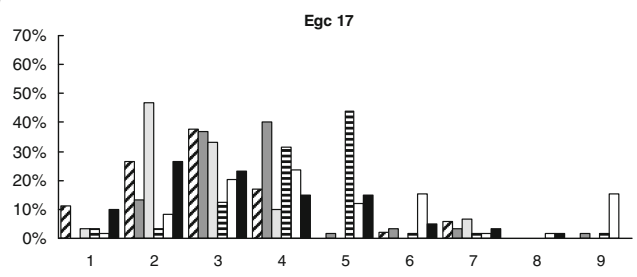

F)

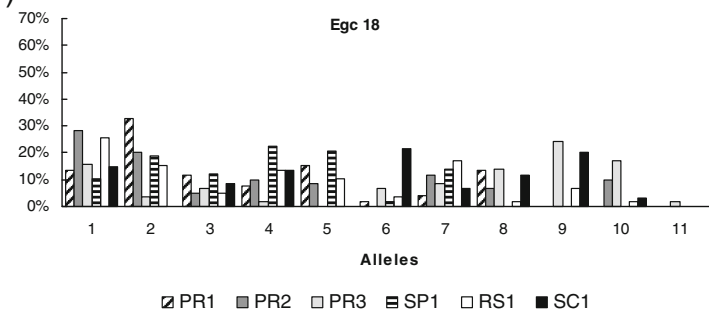

Figure 2. Microsatellite allele frequencies in populations of $E$. violacea from six Brazilian localities. For localities, see Table I. Number of individuals analysed was 53 for population PR1 and 60 for all other populations.

The genetic differentiation (allelic frequency differences) for each pairwise population compar-

Table III. Pairwise $\Phi_{\mathrm{ST}}$ values and pairwise $D_{\text {est }}$ differentiation estimates.

\begin{tabular}{lllllll}
\hline & PR1 & PR2 & PR3 & SP1 & RS1 & SC1 \\
\hline PR1 & - & 0.10 & 0.10 & 0.17 & 0.10 & 0.07 \\
PR2 & 0.04 & - & 0.23 & 0.09 & 0.06 & 0.11 \\
PR3 & 0.04 & 0.08 & - & 0.32 & 0.14 & 0.05 \\
SP1 & 0.06 & 0.04 & 0.11 & - & 0.09 & 0.14 \\
RS1 & 0.03 & 0.02 & 0.05 & 0.03 & - & 0.05 \\
SC1 & 0.03 & 0.04 & 0.02 & 0.05 & 0.02 & - \\
\hline
\end{tabular}

Pairwise $\Phi_{\mathrm{ST}}$ values are shown below diagonal and pairwise $D_{\text {est }}$ differentiation estimates above the diagonal. All $\Phi_{\mathrm{ST}}$ and $D_{\text {est }}$ pairwise estimates were significant $(P<0.05)$. For details about the localities, see Table I ison was found to be significantly different from zero $(P<0.01)$ for all pairs analysed, ranging from 0.02 to 0.11 (Table III). The highest measures of $\Phi_{\mathrm{ST}}$ were detected for the following three pairwise comparisons: PR1-SP1 $\left(\Phi_{\mathrm{ST}}=0.06\right)$, PR2-PR3 $\left(\Phi_{\mathrm{ST}}=0.08\right)$ and PR3-SP1 $\left(\Phi_{\mathrm{ST}}=0.11\right)$ (Table III). However, as shown in Table III, considerably higher genetic differentiation values were revealed by Jost's (2008) estimator. $D_{\text {est }}$ values ranged from 0.05 to 0.32 , and also in this case, the highest estimates of genetic differentiation were found between pairwise comparisons PR1-SP1 $\left(D_{\text {est }}=0.17\right)$, PR2-PR3 $\left(D_{\text {est }}=0.23\right)$ and PR3-SP1 $\left(D_{\text {est }}=0.32\right)$ (Table III). Despite the highest genetic differentiation measures detected by the $D_{\text {est }}$ estimator, a highly significant positive correlation $(P<0.001)$ between both $\Phi_{\mathrm{ST}}$ and $D_{\text {est }}$ was detected, indicating that measures provide similar relative estimates of population differentiation. 
No significant correlation was found between geographical distance and genetic distance $\left[\Phi_{\mathrm{ST}} /\right.$ $\left(1-\Phi_{\mathrm{ST}}\right)$ or $\left.D_{\text {est }} /\left(1-D_{\text {est }}\right)\right]$ (Figure 3$)$.

\section{DISCUSSION}

Our findings on the population genetic structure of E. violacea across the Atlantic Forest fragments revealed a significant genetic differentiation between all pairs of populations analysed. In fact, if we consider the large geographical distances between most of populations here analysed, this result was somewhat expected. Similarly, Zimmermann et al. (2011) analysing seven populations of Euglossa dilemma also distributed over a large spatial scale throughout southern Mexico, based on three microsatellite loci, found significant values of $F_{\mathrm{ST}}$ for some pairs of populations. However, differently of our results, these authors have detected a significant correlation between genetic differentiation and geographical distances of E. dilemma populations from different localities, indicating that their findings are in agreement with IBD model (Rousset 1997). In our study, there are some possible explanations for the lack of association between measures of genetic differentiation and geographical distances found for populations of E. violacea. First, small sample size, as suggested by Ellis et al. (2006). Although Zimmermann et al. (2011) have detected a significant trend of IBD in just seven populations of E. dilemma, the recommended minimum number of samples to detect a signal of IBD is 15 populations (Peterson and Denno 1998). These authors emphasize that with fewer than 15 populations, erroneous conclusions about IBD could be taken. Second, lack of migration-drift equilibrium (Hutchison and Templeton 1999), and third, recent loss of habitat and isolation. A study on the population genetic structure of Bombus sylvarum also detected similar lack of IBD, attributing as possible causes to this finding recent fragmentation and drift in isolated populations (Ellis et al. 2006). Also, the lack of IBD could simply indicate long separated populations, which show no gene flow between them. Even though in this case individual populations could be in mutation-drift equilibrium, genetic drift may influence the degree of relatedness between these populations (Ellis et al. 2006).

Studies on population genetic structure of euglossine bees carried out in a regional scale have reported absence of population structuring (Sofia et al. 2005; Waldschmidt et al. 2005; Rocha Filho 2011) or low levels of genetic differentiation between populations (Cerântola et al. 2011). These findings have been attributed to the high capability of euglossine to disperse, especially males (Sofia et al. 2005; Waldschmidt et al. 2005; Cerântola et al. 2011; Rocha Filho 2011). Concerning our results on genetic differentiation levels, revealed by both estimators $\left(\Phi_{\mathrm{ST}}\right.$ and $D_{\text {est }}$ ), while the measures of $\Phi_{\mathrm{ST}}$ were indicative that samples of $E$. violacea constitute subpopulations exhibiting from low to moderate genetic differentiation among them (see Hartl and Clark 1997), Jost's estimator $\left(D_{\text {est }}\right)$ indicated from low to very high genetic differentiation between pairs of subpopulations. In general, $D_{\text {est }}$ showed higher genetic differentiation between pairs of subpopulations than that indicated by
Figure 3. Relationship between the logarithm of geographical distance and genetic distance [measured as $\left.\Phi_{\mathrm{ST}} /\left(1-\Phi_{\mathrm{ST}}\right)\right]$ across the six Atlantic Forest populations of $E$. violacea in pairwise comparisons. Minimum distance was $130 \mathrm{~km}$ (SC1-RS1) and maximum distance was $850 \mathrm{~km}$ (SP1-RS1).

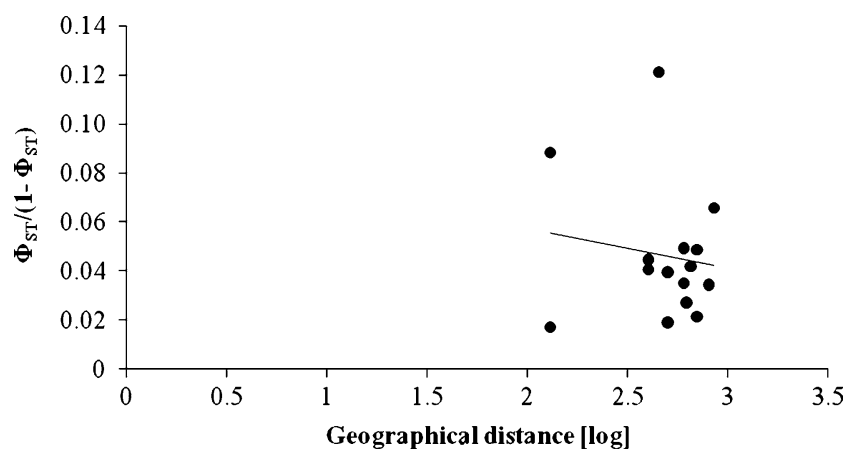


$\Phi_{\mathrm{ST}}$, and that for the PR3-SP1 and PR3-PR2 pairwise comparisons, this differentiation was very high. Similar findings were reported by Davis et al. (2010), when these authors applied both estimators to a population structure analysis of the solitary mining bee Colletes floralis (Eversmann). Also, Souza et al. (2010) computed estimates of genetic differentiation to infer population connectivity between populations of E. violacea from two sites located in southeastern Brazil and separated by about $500 \mathrm{~km}$; this study found that the measure of $F_{\mathrm{ST}}$ was lower than that detected by $G_{\mathrm{ST}}^{\prime}$, although in this case no significant statistical difference was detected. $G_{\text {ST }}^{\prime}$ is an estimator proposed by Hedrick (2005) that takes into account the locus-specific levels of genetic variation within each population and rescales differentiation to between 0 and 1 . Both Hedrick (2005) and Jost (2008) maintain that $F_{\mathrm{ST}}, G_{\mathrm{ST}}$ and its relatives, such as $\Phi_{\mathrm{ST}}$, usually underestimate genetic differentiation since these measures were developed for low-diversity systems or less polymorphic loci, while for highly polymorphic loci, these approaches apparently provide no information concerning the real degree of genetic differentiation between subpopulations (for details, see Jost 2008).

In our study, both analyses $\left(\Phi_{\mathrm{ST}}\right.$ and $\left.D_{\text {est }}\right)$ revealed that the pairwise comparisons PR3SP1 and PR3-PR2 showed the highest measures of genetic differentiation in comparison to the other pairs of populations analysed. In addition, despite the absence of important differences in genetic variation or in the allele composition in samples from different sites, notable variations in allele frequencies among populations, especially for the most variable loci, indicate divergences between some pairs of populations. Thus, the high measures of $D_{\text {est }}$ found seem more consistent than the $\Phi_{\mathrm{ST}}$ estimates, reinforcing Jost's (2008) conviction; this could be attributed to the possible effects of genetic drift. Taking into account that E. violacea is a univoltine species (Peruquetti and Campos 1997), which demands large fragments to maintain its large populations and is usually absent or found in small numbers in small forest fragments (Giangarelli et al. 2009), it would be expected that the effects of genetic drift would take more time to become conspicuous. Population genetic models show that substantial differences in allele frequency will not occur over a short period of time except through selection or low effective population size, either continuously or as a result of transient bottlenecks leading to differentiation due to drift (Ferguson et al. 1995).

The simplest measure of genetic diversity at a locus is the number of alleles or allelic richness (Kalinowski 2004). However, this author points out that this measure is highly dependent on sample size, since larger samples should contain more alleles compared to smaller ones. In our study, the similar numbers of alleles found for different loci and the different populations analysed suggest that no important bias could be expected for this parameter of genetic diversity, since similar sample sizes were surveyed. Concerning the number of alleles detected at different microsatellite loci, a strong similarity was found between the present results and those reported by Souza et al. (2010), who genotyped 53 males of $E$. violacea with the help of an autosequencer. Similarities were also found in the base pair length of the alleles detected in both studies, indicating that no bias in the data resulted from differences in the methodologies used in these studies.

In recent years, studies have assessed the genetic diversity of some Euglossini bee populations using RAPD, microsatellites and allozyme markers (Sofia et al. 2005; Cerântola et al. 2011; Rocha Filho 2011; Zimmermann et al. 2011). In general, these authors have reported high values of heterozygosity (observed and/or expected) for the populations surveyed. Comparing our findings with these studies, the levels of expected heterozygosity found for E. violacea could be considered high. However, on the other hand, it is difficult to evaluate here if the estimates of expected heterozygosity are really higher or lower than could be expected since we do not have any non-fragmented population to compare with the fragmented populations of $E$. violacea surveyed.

Overall, based on the levels of genetic diversity showed by all populations of $E$. 
violacea studied here, we can consider that these populations are not under risk of suffering immediate genetic diversity decline. On the other hand, the present results on the population structure of $E$. violacea suggest a restriction in gene flow among populations from different Atlantic Forest remnants, the persistence of which in the long term could promote significant changes in genetic structure and diversity across populations of this species. Thus, considering the intense threats over the current Atlantic Forest remnants, more attention should be paid to populations of this euglossine species.

\section{ACKNOWLEDGEMENTS}

We thank CAPES (Coordination for the Improvement of Higher Level of Education Personnel) and CNPq (Brazilian Council for Scientific and Technological Development) agencies as well as Klabin S.A. for the financial support of this work (grants nos. CAPES-PROCAD/158/2007 and CNPq-476254/ 2008-6). We are also thankful to Centro de Pesquisas e Conservação da Natureza Pro-Mata (PUC Rio Grande do Sul), EPAGRI (Santa Catarina), Escola Superior de Conservação Ambiental e Sustentabilidade (São Paulo); IAP (Instituto Ambiental do Paraná) and IBAMA (Instituto Brasileiro do Meio Ambiente e dos Recursos Naturais Renováveis) for permission to collect bees and to Douglas C. Giangarelli and Karen M. Suzuki for helping during the samplings. G.A. Freiria and J.B. Ruim, respectively, acknowledge CAPES and Fundação Araucária for the scholarship grants. We also thank two anonymous referees for providing many insightful comments.

Structure de la population et diversité génétique de l'abeille à orchidée Eufriesea violacea (Hymenoptera, Apidae, Euglossini) dans les zones résiduelles de la forêt atlantique du sud et du sud-est du Brésil.

Variabilité génétique / abeille euglossine / forêt résiduelle / microsatellites

Populationsstruktur und genetische Variabilität der Prachtbiene Eufriesea violacea (Hymenoptera, Apidae, Euglossini)in Restbeständen des Atlantischen Regenswalds in Südost- und Südbrasilien.
Genetische Variabilität / Euglossinen / Waldfragmente / Mikrosatelliten

\section{REFERENCES}

Ackerman, J.D. (1983) Euglossine bee pollination of the orchid, Cochleanthes lipscombiae: a food source mimic. Am. J. Bot. 70, 830-834

Biesmeijer, J.C., Roberts, S.P.M., Reemer, M., Ohlemuller, R., Edwards, M., Peeters, T., Schaffers, A.P., Potts, S. G., Kleukers, R., Thomas, C.D., Settele, J., Kunin, W. E. (2006) Parallel declines in pollinators and insectpollinated plants in Britain and the Netherlands. Science 313, 351-354

Brosi, B.J. (2009) The effects of forest fragmentation on Euglossini bee communities (Hymenoptera: Apidae: Euglossini). Conserv. Biol. 142, 414-423

Brosi, B.J., Daily, G.C., Shih, T.M., Oviedo, F., Durán, G. (2008) The effects of forest fragmentation on bee communities in tropical countryside. J. Appl. Ecol. 45, 773-783

Cameron, S.A. (2004) Phylogeny and biology of Neotropical orchid bees (Euglossini). Annu. Rev. Entomol. 49, 377-404

Cane, J.H. (2001) Habitat fragmentation and native bees: a premature verdict? Conserv. Ecol. 5, 3

Cerântola, N.C.M., Oi, C.A., Cervini, M., Del Lama, M. A. (2011) Genetic differentiation of urban populations of Euglossa cordata from the state of São Paulo, Brazil. Apidologie 42, 214-222

Chao, A., Shen, T.J. (2003) Program SPADE (Species Prediction and Diversity Estimation). Computer software distributed by authors, [online] http:// chao.stat.nthu.edu.tw/softwareCE.html (accessed on 24 January 2011)

Davis, E.S., Murray, T.E., Fitzpatrick, U., Brown, M.J.F., Paxton, R.J. (2010) Landscape effects on extremely fragmented populations of a rare solitary bee, Colletes floraris. Mol. Ecol. 19, 4922-4935

Dressler, R.L. (1982) Biology of orchid bees (Euglossini). Annu. Rev. Ecol. Syst. 13, 373-394

Ellis, J.S., Knight, M.E., Darvill, B., Goulson, D. (2006) Extremely low effective population sizes, genetic structuring and reduced genetic diversity in a threatened bumblebee species, Bombus sylvarum (Hymenoptera: Apidae). Mol. Ecol. 15, 4375-4386

Excoffier, L., Lischer, H.E.L. (2010) Arlequin suite version 3.5: A new series of programs to perform population genetics analyses under Linux and Windows. Mol. Ecol. Resour. 10, 564-567

Ferguson, A.J.B.T., Prodöhl, P.A., Mcmeel, O., Thompson, C., Stone, C., Mcginnity, P., Hynes, R.A. (1995) The application of molecular markers to the study and conservation of fish population, with special reference to Salmo. J. Fish Biol. 47, 103-126 
Freitas, B.M., Imperatriz-Fonseca, V.L., Medina, L.M., Kleinert, Ad.M.P., Galetto, L., Nates-Parra, G., Quezada-Euán, J.J.G. (2009) Diversity, threats and conservation of native bees in the Neotropics. Apidologie 40, 332-346

Fundação SOS Mata Atlântica, INPE. (2010) Atlas dos remanescentes florestais da Mata Atlântica período 2008-2010. Dados parciais dos estados avaliados até maio de 2010, São Paulo, Brasil. [online] URL: http:// mapas.sosma.org.br/site_media/download/atlas-rela torio2008-2010parcial.pdf

Gallai, N., Salles, J.M., Settele, J., Vaissière, B.E. (2009) Economic valuation of the vulnerability of world agriculture confronted with pollinator decline. Ecol. Econ. 68, 810-821

Giangarelli, D.C., Freiria, G.A., Colatreli, O.P., Suzuki, K. M., Sofia, S.H. (2009) Eufriesea violacea (Blanchard) (Hymenoptera: Apidae): an orchid bee apparently sensitive to size reduction in forest patches. Neotrop. Entomol. 38, 610-615

Goudet, J. (1995) FSTAT, a program to estimate and test gene diversities and fixation indices (version 2.9.3.2). J. Hered. 85, 485-486

Grixti, J.C., Wong, L.T., Cameron, S.A., Favret, C. (2009) Decline of bumble bees (Bombus) in the North American Midwest. Biol. Conserv. 142, 7584

Hartl, D.L., Clark, A.G. (1997) Principles of population genetics, 3rd edn. Sinauer Associates, Sunderland

Hedrick, P.W. (2005) A standardized genetic differentiation measure. Evolution 59, 1633-1638

Hutchison, D.W., Templeton, A.R. (1999) Correlation of pairwise genetic and geographic distance measure: inferring the relative influences of gene flow and drift on the distribution of genetic variability. Evolution 53, 1898-1914

Jost, L. (2008) Gst and its relatives do not measure differentiation. Mol. Ecol. 17, 4015-4026

Kalinowski, S.T. (2004) Counting alleles with rarefaction: Private alleles and hierarchial sampling designs. Conserv. Genet. 5, 539-543

Kevan, P.G., Phillips, T.P. (2001) The economic impacts of pollinator declines: an approach to assessing the consequences, Ecol. Soc. 5, 8. [online] URL: http:// www.consecol.org/vol5/iss1/art8/

Kimsey, L.S. (1982) Systematics of bees of the genus Eufriesea (Hymenoptera, Apidae). Univ. California Publ. Entom. 95, 1-125

Klein, A.M., Vaissière, B.E., Cane, J.H., SteffanDewenter, I., Cunningham, S.A., Kremen, C., Tscharntke, T. (2007) Importance of pollinators in changing landscapes for world crops. Proc. R. Soc. Lond., Ser. B Biol Sci. 274, 303-313

Kremen, C., Williams, N.M., Thorp, R.W. (2002) Crop pollination from native bees at risk from agricultural intensification. Proc. Natl. Acad. Sci. USA 99, 16812-16816
Kremen, C., Williams, N.M., Aizen, M.A., GemmillHerren, B., LeBuhn, G., Minckley, R., Packer, L., Potts, S.G., Roulston, T., Steffan-Dewenter, I., Vázquez, D.P., Winfree, R., Adams, L., Crone, E. E., Greenleaf, S.S., Keitt, T.H., Klein, A.M., Regetz, J., Ricketts, T.H. (2007) Pollination and other ecosystem services produced by mobile organisms: a conceptual framework for the effects of landscape change. Ecol. Lett. 10, 299-314

López-Uribe, M.M., Almanza, M.T., Ordonez, M. (2007) Diploid male frequencies in Colombian population of Euglossine bees. Biotropica 39, 660662

Martins, A.C., Melo, G.A.R. (2010) Has the bumblebee Bombus bellicosus gone extinct in the northern portion of its distribution range in Brazil? J. Insect Conserv. 14, 207-210

Miller, M.P. (1997) Tools for population genetic analyses (TFPGA) 1.3: A Windows program for the analysis of allozyme and molecular population genetic data. Computer software distributed by author

Morellato, L.P.C., Haddad, C.F.B. (2000) Introduction: the Brazilian Atlantic Forest. Biotropica 32, 786792

Murray, T.E., Kuhlmann, M., Potts, S.G. (2009) Conservation ecology of bees: populations, species and communities. Apidologie 40, 211-236

Myers, N., Mittermeier, R.A., Mittermeier, C.G., Fonseca, G.A.B., Kent, J. (2000) Biodiversity hotspots for conservation priorities. Nature 403, 853-858

Neff, J.L., Simpson, B.B. (1993) Bees, pollination systems and plant diversity. In: LaSalle, J., Gauld, I.D. (eds.) Hymenoptera and biodiversity. CAB International, Wallingford

Nemésio, A. (2009) Orchid bees (Hymenoptera: Apidae) of Brazilian Atlantic Forest. Zootaxa 2041, 1-242

Nemésio, A., Silveira, F.A. (2007) Diversity and distribution of orchid bees (Hymenoptera: Apidae) with a revised checklist of their species. Neotrop. Entomol. 36, 874-888

Peruquetti, R.C., Campos, L.A.O. (1997) Aspectos da biologia de Euplusia violacea (Blanchard) (Hymenoptera, Apidae, Euglossini). Rev. Bras. Zool. 14, 91-97

Peruquetti, R.C., Campos, L.A.O., Coelho, C.D.P., Abrantes, C.V.M., Lisboa, L.C.O. (1999) Abelhas Euglossini (Apidae) de áreas de Mata Atlântica: abundância, riqueza e aspectos biológicos. Rev. Bras. Zool. 16, 101-118

Peterson, M.A., Denno, R.F. (1998) The influence of dispersal and diet breadth on patterns of genetic isolation by distance in phytophagous insects. Am. Nat. 152, 428-446

Powell, A.H., Powell, G.V.N. (1987) Populationdynamics of male euglossine bees in Amazonian forest fragments. Biotropica 19, 176-179

Ramírez, S., Roubik, D.W., Skov, C., Pierce, N.E. (2010) Phylogeny, diversification patterns and historical 
biogeography of euglossine orchid bees (Hymenoptera: Apidae). Biol. J. Linn. Soc. 100, 552-572

Ray, J.D. (2000) Fragment Length Calculator: a Windows 95 program for calculating DNA fragment length. J. Hered. 91, 177-178

Raymond, M., Rousset, F. (1995) GENEPOP (version 1.2): population genetics software for exact tests and ecumenicism. J. Hered. 86, 248-249

Ribeiro, M.C., Metzger, J.P., Martensen, A.C., Ponzoni, F.J., Hirota, M.M. (2009) The Brazilian Atlantic Forest: How much is left, and how is the remaining forest distributed? Implications for conservation. Biol. Conserv. 142, 1141-1153

Rice, W.R. (1989) Analyzing tables of statistical tests. Evolution 43, 223-225

Rocha Filho, L.C. (2011) Estrutura genética e ecologia de comunidades das abelhas Euglossini (Hymenoptera; Apidae) do Parque Estadual da Serra do Mar e Parque Estadual da Ilha Anchieta, Ubatuba, SP, Brasil. PhD Thesis, Faculdade de Filosofia Ciências e Letras de Ribeirão Preto, Universidade de São Paulo, Ribeirão Preto, Brazil

Roubik, D.W., Hanson, P.H. (2004) Abejas de orquídeas de la America Tropical. Biología y guía de campo (Orchid bees of Tropical América) Biology and field guide. INBio Press, Santo Domingo de Heredia

Rousset, F. (1997) Genetic differentiation and estimation of gene flow from F-statistics under isolation by distance. Genetics 145, 1219-1218

Rousset, F. (2008) Genepop'007: a complete reimplementation of the Genepop software for Windows and Linux. Mol. Ecol. Resour. 8, 103-106

Sofia, S.H., Suzuki, K.M. (2004) Comunidades de machos de abelhas Euglossina (Hymenoptera: Apidae) em fragmentos florestais no sul do Brasil. Neotrop. Entomol. 33, 693-702
Sofia, S.H., Paula, F.M., Santos, A.M., Almeida, F.S., Sodré, L.M.K. (2005) Genetic structure analyses of Eufriesea violacea (Hymenoptera, Apidae) populations from southern Brazilian Atlantic rainforest remnants. Genet. Mol. Biol. 28, 479-484

Souza, R.O., Cervini, M., Del Lama, M.A., Paxton, R.J. (2007) Microsatellite loci for euglossine bees (Hymenoptera, Apidae). Mol. Ecol. Notes 7, $1352-1356$

Souza, R.O., Del Lama, M.A., Cervini, M., Mortari, N., Eltz, T., Zimmermann, Y., Bach, C., Brosi, B.J., Suni, S., Quezada-Euán, J.J.G., Paxton, R.J. (2010) Conservation genetics of neotropical pollinators revisited: microssatellite analysis suggests that diploid males are rare in orchid bees. Evolution 64, 3318-3326

Suzuki, K.M., Arias, M.C., Giangarelli, D.C., Freiria, G. A., Sofia, S.H. (2010) Mitochondrial DNA diversity of orchid bee Euglossa fimbriata (Hymenoptera: Apidae) populations assessed by PCR-RFLP. Biochem. Genet. 48, 326-341

Tonhasca, A., Blackmer, J.L., Albuquerque, G.S. (2002) Abundance and diversity of euglossine bees in the fragmented landscape of the Brazilian Atlantic Forest. Biotropica 34, 416-422

Waldschmidt, A.M., Lopes, L.A., Marco Jr., P., Campos, L.A.O. (2005) Genetics of Euglossini bees (Hymenoptera) in fragments of the Atlantic Forest in the region of Viçosa, MG. Braz. J. Biol. 65, 541-549

Zayed, A. (2009) Bees genetics and conservation. Apidologie 40, 237-262

Zimmermann, Y., Schorkopf, D.L.P., Moritz, R.F.A., Pemberton, R.W., Quezada-Euan, J.J.G., Eltz, T. (2011) Population genetic structure of orchid bees (Euglossini) in anthropogenically altered landscapes. Conserv. Genetic.. doi:10.1007/s10592-011-0221-1 